\title{
Autorzy druków okolicznościowych
publikowanych przez oficyne Johanna Reusnera \\ Autorzy druków okolicznościowych
publikowanych przez oficynę Johanna Reusnera w Królewcu (1640-1665)
}

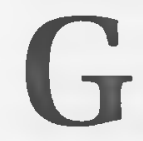

dy zastanawiamy się nad literaturą okolicznościową epoki baroku wyjątkowo na miejscu wydaje się określenie tego zjawiska mianem produkcji. Trafiamy nawet na wyraźne ślady osób lub instytucji, których moglibyśny określić mianem producentów utworów okazjonalnych.

Najpierw uściślijmy, o czym będziemy mówić. Na użytek poniższej wypowiedzi przyjmijmy, ze literatura okolicznościowa to te wypowiedzi (naturalnie mające $z$ założenia charakter literacki), które tworzone przez członków rodziny, przyjaciół $\mathrm{i}$ innych autorów spoza rodziny, upamiętniały doniosłe wydarzenia życia rodzinnego takie jak: narodziny, chrzest, zaślubiny, śmierć i pogrzeb. Wyjątek niech stanowią teksty dotyczące wydarzeń w rodzinach królewskich i książęcych, czyli władców i ich bliskich. W tej grupie, prócz pism $z$ okazji np. narodzin, zaślubin, czy śmierci, pojawiają się utwory powstałe na okoliczność koronacji lub złożenia hołdu. W wypadku członków rodów panujących skłaniałbym się uznać, że niezależnie od tego, czy były to narodziny potomka, zaślubiny, czy może koronacja, zawsze możemy mówić o akcie o charakterze publicznym, a często i politycznym.

Literatura olkolicznościowa funkcjonowała, w interesującym nas okresie, czyli w czasach baroku, równolegle w rękopisach i formie drukowanej. Okres wzmożonej produkcji druków okolicznościowych to XVII i XVIII w. Wydaje się, że w kulturze niemieckiej będzie to głównie XVII w. z najoblitszą produkcją mniej więcej w połowie stulecia, a w Rzeczpospolitej najwięcej druków okolicznościowych ukazywało się nieco później, z ciężarem przesuniętym na XVIII w. ${ }^{\text {. }}$

Zajmiemy się drukowanymi utworami okolicznościowymi. Pod kątem tego rodzaju produkcji przyjrzymy się ofercie królewieckiej oficyny Johanna Reusnera. Drukarnia, o której mowa, wypuściła w ciagu blisko trzydziestu lat działalności (w Królewcu Johann Reusner byl aktywny w od roku 1639 do przekazania tłoczni synowi Fryderykowi w $1665^{2}$ ) ponad tysiąc druków okolicznościowych. Nas interesować będą ich autorzy, zarówno osoby jak i instytucje sprawcze.

Literatura okolicznościowa otaczała zewsząd człowieka baroku, przynajmniej tego wykształconego. Edukacja szkolna przewidywała m.in. naukę pisania tekstów okolicznościowych według przyjętych reguł formalnych. Uczniowie gimnazjów czcili panegirykami rozmaite zclarzenia życia publicznego i rodzinnego. Co celniejsze $z$ utworów byly rozpowszechniane ${ }^{3}$. Formy, które opanowano w procesie edukacji przyszło wylkorzystywać w życiu dorosłym niejednokrotnie. Pisali ci, którzy liczyli na wynagrodzenie, ale też przyjaciele oraz członkowie bliższej lub dalszej rodziny. Inicjatorami powstania i publikacji utworów 
okolicznościowych były też instytucje. W przypadku siedemnastowiecznego Królewca niezawodnym dostawcą literatury okolicznościowej był Uniwersytet.

Utwór okolicznościowy miał charakter panegiryczny, wskazywał wzorce osobowe, był nieodlącznym literackim elementem, obowiazkowym składnikiem scenariusza uroczystości rodzinnych, pełnił funkcję informacyjną, czyli mieścił się w systemie komunikacji, wreszcie był nie tylko dowoclem pamięci, ale sposobem na pozyskanie przychylności roclziny, której członków dotyczył, lub, i to być może nie na miejscu ostatnim, źródłem zarobku.

Kim byli autorzy utworów okolicznościowych? Za materiał i podstawę clalszych dociekań niech nam posłużą publikacje o charakterze okazjonalnym ze wspomnianej powyżej drukarni Johanna Reusnera w Królewcu.

Już przy pobieżnym przyjrzeniu się zebranemu materiałowi wyraźnie rysuje się pewien obraz. Można go krótko opisać słowami: autorzy ponad tysiąca utworów okolicznościowych opublikowanych przez Johanna Reusnera to: Simon Dach (ponad polowa całego zbioru), Uniwersytet (ok. 20\%) i killkuclziesięciu autorów pozostałych (mniej więcej 1/3) tekstów.

Aktywność Uniwersytetu nie dziwi. Z uczelnią związane były najwybitniejsze postaci Królewca, elita naukowa i intelektualna Prus Książęcych. Przecież Uniwersytet powstał po to, by kształcić duchownych i urzędników na potrzeby młodego protestanckiego państwa. Elitę budowała zarówno kadra szkoły jak i pozostający w Prusach jej absolwenci. Jak wynika $z$ analizy zebranego materiału, osoby, które zaliczymy do tej grupy należały częstokroć clo bohaterów druków okolicznościowych opublikowanych pod egidą uczelni, ale i same należały do autorów poezji casualnej.

Druki okolicznościowe podpisywane: „Rector et Senatus Academiae Regiomontanae", to w dużej mierze zaproszenia na pogrzeby wykładowców uczelni i członków ich rodzin, druki upamiętniające burmistrzów i członków rady miejskiej oraz ich rodziny, urzędników dworu książęcego i członków znacznych rodzin pruskich. Dużą grupę stanowią panegiryki na cześć księcia elektora i jego najbliższych (chociażby publikacje z okazji rocznic urodzin Fryderyka Wilhelma i jego syna Karola Emila).

Uczelnia pamiętała tė̇ o monarchach Rzeczpospolitej. W 1649 r. ukazały się w drukarni Johanna Reusnera dwa panegiryki upaniętniające Władysława IV oraz, także dwa, na cześć Jana Kazimierza ${ }^{4}$. Wszystkie wydane w imieniu uczelni, ale autorstwa Valentina Thilo. Częstokroć Valentin Thilo, profesor retoryki, wielokrotny dzielkan wydziału filozoficznego oraz dwukrotny rektor królewieckiej akademii, był autorem druków okolicznościowych ogłaszanych przez uczelnię.

Wśród osób, dla których znalazło się miejsce na stronach druków okolicznościowych wypuszczonych przez Albertinę były m.in.: zmarły w 1659 r. wspomniany juz niezmiernie płodny poeta niemieckiego baroku, profesor poezji, rektor uniwersytetu w Królewcu, centralna postać Koenigsberger Dichterkreis Simon Dach ${ }^{5}$, Barbara Friese wclowa po Johannie Friese ${ }^{6}$ burmistrzu Knipawy (jednej z trzech części Królewca), czy pochodzący z Gdańska student teologi Andreas Walther ${ }^{7}$.

Przykłady te pozwalają zarysować krąg osób, których dotyczyły utwory okolicznościowe publikowane w imieniu Uniwersytetu. Były to postacie ściśle 
związane $z$ uczelnia, jej profesorowie i studenci, członkowie rodzin wykładowców, burmistrzowie, radcy i inni urzędnicy miejscy wraz z rodzinami. Poza nimi w grupie tej znaleźli się urzędnicy dworu książęcego, prawnicy, lekarze, pastorzy i kaznodzieje (przede wszystkim z Królewca i innych miast pruskich, ale także spoza terenów Prus Ksiązęcych) oraz członkowie szlacheckich rodzin pruskich. Część z nich miało za sobą studia w Albertinie.

Jedną $z$ osób związanych przez lata $z$ miastem i $z$ Uniwersytetem był Simon Dach, autor około sześciuset, opublikowanych u Johanna Reusnera, tekstów okolicznościowych ${ }^{8}$. W latach najwięliszej aktywności pisarskiej S. Dacha casualia jego autorstwa stanowiły znaczny procent ogółu publikacji okolicznościowych tłoczonych przez Reusnera (w 1652 r. stanowiły ponad 80\%). Wraz ze śmiercią poety w 1659 r., prawie o połowę maleje liczba utworów okolicznościowych $w$ olercie omawianej oficyny. Czy śmierć tak barclzo plodnego autora mogła być przyczyną nagłego załamania produkcji druków okazjonalnych w interesującej nas oficynie? Czyżby Simon Dach był niezastąpiony?

Wygląda na to, że lata 60 . siedemnastego wieku w drukarni Reusnera, to olkres coraz mniejszej produkcji druków okazjonalnych. Być może ma to związek z ogólna tendencją i powolnym zanikaniem mody na tego rodzaju publikacje, może także $z$ tym, że Johann Reusner po 1663 r., po śmierci żony, zaczyna wycofywać się $z$ interesów ${ }^{9}$.

Wróćmy jeszcze na chwile do utworów autora "Annchen von Tharau". Simon Dach pisał i publikował u Reusnera panegiryki poświęcone prolesorom Uniwersytetu $\mathrm{i}$ ich rodzinom, postaciom związanym $z$ dworem książęcym, członkom znacznych pruskich rodzin szlacheckich albo mieszczańskich, ale także swym przyjaciolom, towarzyszom z grupy „Koenigsberger Dichterkreis”, którą wiązało zamiłowanie do joezji ${ }^{10}$ lub najbliższym. Daje się zauważyć, że stosunkowo niewiele panegirylków poświęcił roclzinie księcia elektora i jemu samemu.

Oprócz druków zawierających wyłącznie teksty Dacha, znajdziemy publikacje obejmujące wiersze kilku autorów. S. Dach jest często jednym z nich. Zazwyczaj prace te upamiętniały wspólnego przyjaciela autorów publikowanych razem tekstów.

Myślę, że można przyjąć, że dla Dacha pisanie utworów okolicznościowych było żródłem zarobku. Takiego zdania jest Gerhard Dünnhaupt autor „Personalbibliographien zu den Drucker des Barock", który pisząc o królewieckich latach studenckich poety stwierdza, że „Wie so viele minclerbemittelte Stuclenten schlug er sich zunächst mit Privatunterricht durch und begann zugleich, sich mit Gelegenheitsdichtungen zu Hochzeiten und Begräbnissen einen Nebenerwerb zu schalfen" ${ }^{\text {"1 }}$. Prawdopodobnie udlało się Dachowi rlo tego stopnia wyrobić sobie markę, jak byśmy dziś używając kolokwializmu powiedzieli, że znajdował przez lata licznych odbiorców swojej twórczości (Dünnhaupt pisze o 3-4 publikacjach okolicznościowych tygodniowo ${ }^{12}$, a to oznacza rzeczywiście duże zapotrzebowanie na utwory Dacha).

Do osób związanych z królewiecką grupą poetycką i tym samym z Simonem Dachem należał pochodzący ze Śląska poeta Krzysztof Kaldenbach. Pisał on wiersze niemieckie, łacińskie, greckie, hebrajskie oraz polskie. Polszczyzną posługiwał się ponoć równie dobrze jak językiem niemieckim, czy łaciną. Jego 
autorstwa jest jedyny w omawianym zbiorze utwór opublikowany w języlku polskim „Hołdowna Klio...” z 1641 r., czyli panegiryk powstały z okazji zlożenia hołdu lennego przez Fryderyka Wilhelma ${ }^{13}$. W tym samym roku Kaldenbach wyclał laciński wiersz, którym uczcił ślub Simona Dacha z Reginą Pohl ${ }^{14}$.

Autorami około trzeciej części druków okolicznościowych, które wyszły spod pras Johanna Reusnera, były osoby na co dzień nie mające wiele wspólnego $z$ twórczością literacką. Przypomnijmy: czasy baroku to okres, w którym jednym z podstawowych elementów edukacji była nauka pisania utworów okolicznościowych. Każdy, kto kończył szkołę, potrafił według podanych wzorów (może właściwiej powiedzieć, szablonów) lepiej lub gorzej złożyć panegiryk. Powstawały zatem masowo i byly publikowane teksty okolicznościowe, których autorami byli duchowni, lekarze, prawnicy, dziedzice na włościach, dworzanie oraz studenci, przyjaciele i krewni. Nie inaczej rzecz miała się w Królewcu. Tłocznia Johanna Reusnera wypuściła m.in. panegiryki podpisane: „geführet von Joachim Sigismundt von Bock. Nob: March" ", „Cyriacus Heilsberger Jun. Th. Stud.." , „Gehalten und... zum Druck übergeben Durch M. Urbanum Lepnerum, Der Altstältischen Kirchen Archi-Diaconum" ${ }^{17}$ albo te $\dot{z}$ "An meinen Hertzliebsten Freunde...", jak zwracał się teolog Abraham Calov do Johanna Lösel cledykując mu utwór $z$ olkazji jego ślubu $z$ Katarzyną Lepner ${ }^{18}$, czy wreszcie "dicata a fautoribus, collegis et Amicis” w zbiorze wierszy, których autorami byli głównie wykładowcy Albertiny oraz członkowie „Königsberger Dichterkreis"19.

Druki okolicznościowe $z$ oficyny Johanna Reusnera towarzyszyły zyciu wykształconych warstw społeczeństwa Prus Książęcych przez prawie trzydzieści lat. Za ich pośrednictwem możemy obserwować dzieje rodzinne, przyjaźnie, zależności, hierarchie czy wreszcie przyjęte formy zachowań. Po ich lekturze bliższa staje się siedemnastowieczna kultura i obyczajowość. Wiele daje samo zestawienie podstawowych clanych zawartych na ich stronach. Pojawiają się kolejne pytania o komunikację i rolę druku, a także o społeczny charakter słowa drukowanego w czasach baroku. Mimo, ze materiał, jakim są nieprzeliczone casualia, na pierwszy rzut oka wydaje się być niewdzięczny i wymagający żmudnego, nużącego chwilami opracowania (tak jest w istocie). Jednak to, co daje w zamian za nasz wysiłek, wynagradza nasz trud.

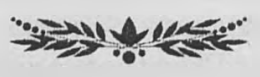

\section{Przypisy:}

${ }^{1}$ R. Lenz, De mortuis nil nisi bene? Leichenpredigten als multidisziplinäre Quelle, Sigmaringen 1990, s. 17-18; E. Kizik, Wesele, kilka chrztów i pogrzebów. Uroczystości rodzinne w mieście hanzeatyckim od XVI do XVII wieku, Gdańsk 2001, s. 134-136; I. Imańska, Druk okolicznościowy jako wielofunkcyjny środek przekazu w czasach saskich, Torun 2000, s. 111-112; B. Rok, Druki żałobne w dawnej Polsce XVI-XVII w., w: Wesela, chrzciny i pogrzeby $w$ XV-XVII wieku. Kultura życia $i$ śmierci, Warszawa 2001, s. 200. 
${ }^{2}$ Drukarze dawnej Polski od XV do XVIII wieku, t. 4, Pomorze, oprac. A. KaweckaGryczowa oraz K. Korotajowa, Wroclaw, Kraków 1962, s. 335-342.

${ }^{3} \mathrm{O}$ obyczaju upubliczniania co ciekawszych utworów okolicznościowych autorstwa uczniów gimnazjum elbląskiego pisze E. Kizik, op. cit. s. 130-131.

${ }^{4}$ Ad panegyrin solennem, qva immortali honori... invictissimi... Vlaclislai IV Poloniae regis... parentalia pvblica Academia Regiomontana ore Val. Thilonis orat. p.p. ipso exeqviarvm clie, qvi XIV Janvarii erit... institvet, domini maecenates, favtores, amici ac cives svbmisse, officiose, amice invitantvr. [Królewiec, 1649]. Vladislavs Magnvs sive Invictissima... domini Vladislai IV electi Polonorum... Regis... magnitudo parentalis muneris loco ipso exequiarum die nomine Rectoris et Senatus Academiae Regiomontanae humilime proposita a Val. Thilone... Regiomonti, 1649. Ad panegyrin academican, qva serenissimo... domino Johanni Casimiro, Poloniae electo... adversvs seditiosos cives profecto, felicem expeditionem nobilissimi atcve ornatissimi jvvenes fvtvro XXIIl Jvlii... in avditorio majori precabvntvr, maecenates, favtores, amicos ac cives ac academicos officiose, amice invitat Val. Thilo p.p. Regiomonti, 1649. Vota pvblica pro felici serenissimi... domini Johannis Casimiri, Poloniae Sveciaegve regis, Magni Dvcis Litlivaniae... adversus seditiosos cives profecti expeditione a nobilissimis atqve eximiis aliqvot juvenibus directore Valentino Thilone, orat. p.p. facta. Regiomonti, 1649.

${ }^{5}$ Honor exequialis viro amplissimo... Simoni Dachio... exhibitus a Rectore et Senatu Academiae Regiomontanae, [Królewiec, 1659].

${ }^{6}$ Ad Exequias Quas Vir... Dn. Johannes Friese Curiae Cniphovianae Consularis, Et Camerarius Dignissimus Desideratissimae Coniugi Suae Barbarae Bierwuffin... Faciet Invitat Cives Suos Rector Et Senatus Academiae Regiomontanae, Regiomonti, 1651.

${ }^{7}$ Invitatio Ad Funus, Praestantissini \& Humanissimi Iuvenis, Andreae Waltheri Dantiscani S.S. Theologiae Studiosi, Proposita A Rectore Et Senatu Academiae Regiomontanae, Regiomonti, 1646.

${ }^{8}$ W zebranym materiale casualiów pióra Simona Dacha jest 590 , do tego doliczyć należy mniejsze utwory opublikowane pod wspólnym tytulem wraz z tekstami innych autorów i publikacje $z$ innych oficyn. Wg. biografów S. Dach jest autorem prawie 1300 pulJlikacji okolicznościowych. Zob. np.: Simon Dach und Königsberger Dichterkreis. Hrsg. von Altired Kelletat, Stuttgart 1986, s. 297.

${ }^{9}$ Drukarze dawnej Polski od XV do XVIII wieku, t. 4, Ponnorze..., s. 340.

${ }^{10}$ M.in. po śmierci jednego ze wspólzałożycieli grupy Heinricha Alberta powstał utwór: Sehnliche Klage, welche bey...seligem... Ableiben des... Herrn Heinrich Alherten... gefuehret ich Simon Dach 1651. 10. Weinmonat, Koenigsberg, 1651. Pamięci innego bliskiego przyjaciela, zmarłego w 1648 Roberta Rober tina poświęcil S. Dach trzy utwory, które ukazaly się u Reusnera. Są to: Bittere Klage Uber Des weiland GrosAchtbarn Hochgelarten und Weitberühmten H. Robert Roberthins Churfl. Brandenb. Preïssischen Ober- und Regiments-Secretary... Unverhofftem und recht hochbetriibtem aber seligem Hintritt aus dieser Welt... von mir Simon Dachen 1648. 10. Ostermonats-Tag, [Królewiec, 1648]. Epitaphium Amplissimo Consultissimo ... Dn. Roberto Robertino... Simon Dachius, Regiomonti, 1648 oraz wspomnienie prayjaciela Memoria Roberti Robertini Supremo in Borussia reginini quondann a secretis Viri Eruditione, Iudicio, Candore Incomparabilis de re literarja \& de me cumprimis optime meriti renovata a me Simone Dachio. M D CXLIX. IV. Id. April, [Królewiec], 1649.

${ }^{11}$ G. Dünnhaupt, Personalbibliographien zı den Drucken des Barock, Stuttgart, 1990 2. Teil, s. 996. 
${ }^{12}$ Tamże.

${ }^{13} \mathrm{~K}$. Kaldenbach, Holdowna Klio, albo na hold y przysiege, ktore niezwyciezonemu monarsze Whadislawowi IV. polskiemu y szwedzkiemu krolowi... wzgledem krain pruskich nczynilo najasnieysze ksiaze Fryderyk Wilhelm, margrabia brandenburski... W Królewcu, 1641.

${ }^{14}$ K. Kaldenbach, Myrtus Viro Clarissimo M. Sinoni Dachio, Poes. P. P. P. t. Fac. Phil. Decano Spect. Pudicissimae Virgini Reginae Pohliae Sponso scripta a Cluristophoro Caldenbachio, [Królewiec], 1641.

${ }^{15} \mathrm{~J}$. S. von Bock, Schmertzliche Trawer-Klage Als die Hand Gottes den Einen grijnen und frisch-blühenden Zweig von dem Hochlöblichen Stam Brandenburg plötzlich und unverhoftt mit hoch empfindlichem Schaden herunter rieß... Auß schuldiger Pflicht... gefuihret von Joachinn Sigismundt von Bock. Nob: March, Königsberg, 1642

${ }^{16}$ C. Heilsberger, Hochzeit Gedicht zu Ehren... des... Balthasari Schimmelptennings Gerichtsverwandten in der Churfl. Stadt Bartenstein Breuttigans und... Jungfer Mariae Eleonore Brautt Des... Friderici Heilsberg in obgedachter Churfl. Stadt verordneten Ertzpriester und... Seelsorgers... einige Tochter; Koenigsberg, 1640.

${ }^{17}$ U. Lepner, Christliche Leichpredigt... Bey... Leichbegängnïß Des Weyland... Herrn Johannis Masii, ... Gehalten und... zum Druck aibergeben Durch M. Urbanum Lepnerum, Der Altstädtischen Kirchen Archi-Diaconunn, Königsberg, 1642.

${ }^{18}$ A. Calov, An meinen Hertzliebsten Freunde H. D. Johann Lösel Als Ihm Die VielEhr und Tugendtreiche Jungtraw Catharina Lepnerin ellichen beygeleget ward Am 13. Februar. des 1640. Jahrs, Königsberg, 1640.

${ }^{19}$ Carmina votiva nuptiis Michalis Behmii, Theol. D. ...et Annae Pohliae, dicata a fautoribus, collegis et annicis, Regiomonti, 1640. 